\title{
Manichaean exonyms and autonyms (including Augustine's writings)
}

\begin{tabular}{|c|c|}
\hline \multicolumn{2}{|c|}{$\begin{array}{l}\text { Author: } \\
\text { Nils A. Pedersen }{ }^{1,2}\end{array}$} \\
\hline $\begin{array}{l}\text { Affiliations: } \\
{ }^{1} \text { Department o } \\
\text { Society, Aarhus } \\
\text { Denmark }\end{array}$ & $\begin{array}{l}\text { f Culture and } \\
\text { Is University, }\end{array}$ \\
\hline $\begin{array}{l}{ }^{2} \text { Research Fellc } \\
\text { Department of } \\
\text { History and Po } \\
\text { of Pretoria, So }\end{array}$ & $\begin{array}{l}\text { ow, } \\
\text { f Church } \\
\text { lity, University } \\
\text { uth Africa }\end{array}$ \\
\hline $\begin{array}{l}\text { Note: } \\
\text { Contribution to } \\
\text { and Manichae } \\
\text { Christianity', th } \\
\text { South African } \\
\text { on Augustine o } \\
\text { University of P } \\
\text { 24-26 April } 20 \\
\text { Pedersen is pa } \\
\text { research fellon } \\
\text { Hans van Oort, } \\
\text { Extraordinariu } \\
\text { Department of } \\
\text { History and Po } \\
\text { Faculty of The } \\
\text { the University } \\
\text { Pretoria, South }\end{array}$ & $\begin{array}{l}\text { o 'Augustine } \\
\text { he First } \\
\text { Symposium } \\
\text { of Hippo, } \\
\text { retoria, } \\
12 \text {. Dr Nils } \\
\text { articipating as } \\
\text { w of Prof. Dr } \\
\text {, Professor } \\
\text { s in the } \\
\text { f Church } \\
\text { lity of the } \\
\text { ology at } \\
\text { of Pretoria, } \\
\text { h Africa. }\end{array}$ \\
\hline $\begin{array}{l}\text { Corresponden } \\
\text { Nils Pedersen }\end{array}$ & ice to: \\
\hline $\begin{array}{l}\text { Email: } \\
\text { nap@teo.au.d }\end{array}$ & \\
\hline $\begin{array}{l}\text { Postal address } \\
\text { Jens Chr. Skous } \\
\text { Building } 1451 \text {, } \\
8000 \text { Aarhus C }\end{array}$ & $\begin{array}{l}\text { s: } \\
\text { s Vej 7, } \\
\text { Room 426, } \\
\text {, Denmark }\end{array}$ \\
\hline $\begin{array}{l}\text { Dates: } \\
\text { Received: } 02 \mathrm{~N} \\
\text { Accepted: } 10 \mathrm{~J} \\
\text { Published: } 10\end{array}$ & $\begin{array}{l}\text { Vov. } 2012 \\
\text { Jan. } 2013 \\
\text { Apr. } 2013\end{array}$ \\
\hline $\begin{array}{l}\text { How to cite th } \\
\text { Pedersen, N.A. } \\
\text { 'Manichaean e } \\
\text { and autonyms } \\
\text { Augustine's wr } \\
\text { HTS Teologiese } \\
\text { Theological Stu } \\
\text { Art. \#1358, } 7 \text { p } \\
\text { dx.doi.org/10. } \\
\text { v69i1.1358 }\end{array}$ & $\begin{array}{l}\text { is article: } \\
\text { 2013, } \\
\text { exonyms } \\
\text { (including } \\
\text { ritings)', } \\
\text { e Studies/ } \\
\text { udies 69(1), } \\
\text { oages. http:// } \\
4102 / \text { hts. }\end{array}$ \\
\hline 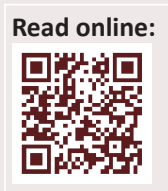 & $\begin{array}{l}\text { Scan this QR } \\
\text { code with your } \\
\text { smart phone or } \\
\text { mobile device } \\
\text { to read online. }\end{array}$ \\
\hline
\end{tabular}

Did the Western Manichaeans call themselves 'Manichaean' and 'Christian'? A survey of the evidence, primarily Latin and Coptic, seems to show that the noun and adjective uses of 'Manichaean' were very rarely used and only in communication with non-Manichaeans. The use of 'Christian' is central in the Latin texts, which, however, is not written for internal use, but with a view to outsiders. The Coptic texts, on the other hand, are written for an internal audience; the word 'Christian' is only found twice and in fragmentary contexts, but it is suggested that some texts advocate a Christian self-understanding (Mani's Epistles, the PsalmBook) whilst others (the Kephalaia) are striving to establish an independent identity. Hence, the Christian self-understanding may reflect both the earliest Manichaeism and its later Western form whilst the attempt to be independent may be a secondary development.

\section{Introduction}

Augustine starts his work On Heresies from the years 428-429 with these words:

I write something on heresies that is worth reading for those who desire to avoid teachings which are contrary to the Christian faith and which, nonetheless, deceive others, because they bear the Christian name. ${ }^{1}$

So basically heresies are teachings that contain an anti-Christian faith, even though they still claim to be Christian. This definition must also include the Manichaeans since they are treated by Augustine in On Heresies, Chapter 46.

By saying that heresies are anti-Christian teachings which still call themselves Christian, Augustine probably had the words of Jesus from Matthew 7:22 in mind. Here Jesus speaks about certain rejected persons who will say to Christ on judgement day: 'Lord, Lord, did we not prophesy in your name, and cast out demons in your name, and do many deeds of power in your name?'

However, the word 'heresies' used by Augustine is not found in Matthew, so it also seems clear that his definition is an echo of an older heresiological topos which was more clear-cut when it was first expressed in Justin Martyr's Dialogue with Trypho, Chapter 35 (Goodspeed 1914). This chapter, which seems to combine Matthew 7:15 and 7:22 and other words of Jesus, states that the heretics should not be named after Christ but only after their heresiarch, the originator of their heresy. This viewpoint was repeated by many subsequent Christian authors and it shows how much the name 'Christian' had become an 'insider' name or autonym, even if it was also the preferred name used by outsiders, for example by persecutors like Pliny (W. Heinemann 1972), as we know from his letter to the Emperor (10:96-97). The crucial question put by Pliny to those who were accused of being Christians was precisely whether they were Christians, and this corresponds with the Christian Martyr literature which often states that the persecutions occurred because of the 'name'. So the name Christian was both an autonym and an exonym, that is, an 'outsider' name. In fact, according to the interpretation of most scholars of Acts 11:26, the name 'Christian' was originally an exonym, coined in Antioch, whilst Acts also uses another name for the Christians: 'the Way' (Ac 9:2; 19:9, 23; 22:4; 24:14, 22) especially in the context of conflict or persecution. In Acts 24:14 it becomes clear that 'the Way' was an insider designation distinguished from the term hairesis used by outsiders at that time. However, it has also been argued that the name of Christians was coined by the Christians themselves with respect to the outside world whilst between themselves the first Christians preferred the names of 'brethren', 'believers', 'Saints' and so forth (cf. Bickerman 1986). This argument illustrates the possibility that a group may have had an autonym only intended for use in communication with outsiders.

Justin Martyr would not allow the heretics to be called Christians, and this shows how dear this name had become to the Christians themselves. This was perhaps due to its central role in the persecutions, but it may also have had something to do with its association with the 
anointments linked to baptism. So exonyms may also have become autonyms, and this raises the question of the origin and function of the names of heretics mentioned by Justin and other church fathers: the heretics called themselves Christians, but the church fathers called them Marcionites, Valentinians, Basilidians, Saturnilians and so on. This could mean that these names were only exonyms used by heresiologists and proto-Orthodox groups. But it is further possible that these groups sometimes also turned exonyms into autonyms and thus actually called themselves Valentinians and Basilidians and the rest.

The fact that the Nag Hammadi texts did not use such names as self-designations, however, raised the suspicion in scholarship that they were solely exonyms used by protoOrthodox authors in order to cast doubt on the Christian character of their adversaries. It should be observed, however, that we have a unique piece of epigraphic evidence as to the use of the name Marcionite, or more precisely Marcionist, as an autonym in an inscription dated 318-319 AD or 630 of the Seleucid era. It was discovered about three miles south of Damascus, but is now unfortunately lost. ${ }^{2}$

With this background in mind, it is natural to ask whether the noun and adjective 'Manichaean' was also only an exonym, never used by the Manichaeans themselves - that is, the groups which were called thus by the outsiders? Recently Richard Lim wrote an article called 'The Nomen Manichaeorum and its uses in Late Antiquity' which also addresses this question (Lim 2008). Initially Lim argues that Secundinus called himself both a Manichaean and Christian in his letter to Augustine, and that the 'Manichaean name' stood for him 'as a badge of honor' (2008:143). 'In thus employing the nomen as a term of praise reserved for the "lovers of truth", Secundinus was', according to Lim, 'distinctly in the minority - even close to being unique - among the extant writers of Late Antiquity' (2008:144). Addressing the history of the label 'Manichaean', Lim furthermore writes that 'at first glance, the nomen Manichaeorum belonged generically to the class of sectarian labels that identifies the follower in reference to the founder of the religion or philosophical sect' (2008:145). He admits that 'insiders often came to embrace terms of abuse by outsiders as sources of positive identity' (2008:146), as was, for instance, the case with the name 'Christian', but he doesn't think that Manichaeans identified themselves in the same way with the label 'Manichaean'. On this basis, Lim draws a number of further conclusions, namely that 'we owe the sense of a distinctive Manichaean identity to the works of catholic/orthodox writers' and 'that people whom we have grown accustomed to calling Manichaeans mainly represented themselves as Christians' (2008:147). Mani called himself an apostle of Jesus Christ, and his followers 'did not always mark themselves off as distinct from [other] Christians' (Lim 2008:149). Mani 'had not insisted upon a distinctive name for his church' (2008:149), and he thinks that Secundinus was 'a philosophically inclined Christian who has chosen to follow the superior teachings of Mani' (2008:160), who perhaps did not hold 'active membership in a socio-religious institution called the Manichaean "church".'3

So according to Lim, the name 'Manichaean' was mainly an exonym and in the very few cases where it was an autonym first and foremost in Secundinus's letter - it was perhaps not a group designation but rather an individual's self-designation implying adherence to the thinking of true philosophers. It was the Christian heresiologists who, according to Lim, constructed 'the Other' and thereby created the nomen manichaeorum. Normally, people called Manichaeans by their adversaries have simply viewed themselves as Christians, and they have not always distinguished themselves from other Christians.

Lim's article contains some very good observations, but still his results are clearly marred by a number of misunderstandings. This is not because I disagree with the viewpoint that the people we call 'Manichaeans' may not always have called themselves so, or that I disagree with the viewpoint that they sometimes called themselves 'Christians'. However, it is important to observe that Mani's writings and the literature building on and celebrating these writings were not suitable as literature for philosophically interested individuals since they always stressed a certain religious community as indispensable for salvation. Lim thinks that scholarship has continued an ancient reification of the identity of Manichaeans being reliant upon a master narrative of Manichaeans as a clearly distinct religious tradition (Lim 2008:150, 154). But for all the differences between Manichaean traditions, they always seem to have been bound up with a special group feeling and an ecclesiastical organisation. Hence it is more probable that the Manichaean literature was only transmitted within this very same community. Still, the question of how this community designated and understood itself is certainly of great interest. In what follows, I will examine Manichaean sources in Latin and Coptic.

It should initially be stressed that the question about Manichaean autonyms is not solved by a reference to the fact that the names Jesus Christ and Mani in the form Manichaios or Manichæus are positively emphasised in Manichaean sources. Even though in some passages Lim argues in this way ${ }^{4}$ it is methodologically wrong. Jesus is for instance also called Messiah in Islam even though Muslims do not understand themselves as Christians, and the important question is whether Manichaios is used not as a personal name but as a designation for members of a group and as an adjective.

Furthermore, I suggest that self-designations for groups should mainly be understood in different contexts, that is,

3.Lim (2008:159), about the Manichaean Julia in Mark the Deacon's Life of Porphyry of Gaza, whom Lim considers to be 'a female counterpart to Secundinus.'

4.Lim (2008:147) argues that the Manichaeans mainly represented themselves as Christians by referring to the fact that Mani referred to himself as an 'apostle of Christians by referring to the fact that Mani referred to himself as an 'apostle of
Jesus Christ'. This reference in itself is, however, insufficient as regards the question of Manichaean autonyms. 
they are identifications dependent on their function. This means that the same group may well have identified itself with different names depending on the contexts in which they were situated.

\section{Manichaean self-designations in the Latin texts}

Looking first at Secundinus's Epistula, ${ }^{5}$ we see that he indirectly confirms the self-designation 'Christian' since he writes that whilst reading Augustine's Confessions he has not discovered a Christian in its author (Secundinus 1891-1892); furthermore he doubts that he was ever a Manichaean since he does not really know Mani's teachings. This means that Secundinus considered both the name 'Manichaean' and the name 'Christian' positive designations which must have been autonyms. The Christian autonym is not surprising if we take the Christian character of Secundinus's Epistula into account, as stressed by Johannes van Oort (2001). Interestingly, Secundinus dissociates himself from his opponent's use of the designation 'Catholic', though not from the word itself. ${ }^{6}$ Even though Secundinus did not find the name 'Manichaean' offensive, I cannot see that his Epistula entitles us to assume that it was a name normally used by him and his coreligionists: the Epistula was not written for internal use in his congregation but for that public, which presumably called Secundinus's co-religionists 'Manichaean'. In principle, of course, this consideration also applies to his use of the name 'Christian' since the Epistula was directed at a public seeing itself as Christian.

Besides the Epistula of Secundinus, the names 'Manichaean' and 'Christian' are also known as autonyms from other Latin texts preserved in connection with Augustine's works; whilst Secundinus was a Manichaean from Rome, these Manichaeans were from North Africa, namely, Fortunatus, Felix and Faustus.

Contra Fortunatum ${ }^{7}$ is not a literary text like the Epistula of Secundinus or the Capitula of Faustus, but are minutes from a public debate. All three texts, however, share the feature of being directed at the outside world, and not at the Manichaean congregations themselves. Fortunatus admitted that he and his co-religionists could be called 'Manichaeans' by saying to Augustine: 'Because I know that you were one of us, that is, that you had a role among the Manichæans, those are the principal points of our faith' (Quia te medium fuisse nostrum scio, id est inter Manichaeos administrasse, ista principalia sunt fidei nostrae') (Augustinus, Contra Fortunatum I, 1; transl. Teske 2006:145). The wording does not suggest that 'Manichaean' was an important autonym for Fortunatus; it rather seems to be the designation of the outside world which Fortunatus, however, had no objections to use and could 5.The English translation used here is in Gardner and Lieu (2004:136-142).

6.Secundinus, Epistula, says about the Devil: 'Afterwards his wickedness grew so far that he devised various problems for him and his apostles who gathered there, under their name, which is all the worse, dividing among all the superstitious the dignity of the term Catholic' (transl. Gardner \& Lieu 2004:139-140).

7.The English translation used here is in Teske (2006), quoted with slightly revised orthography. recognise as a correct identification. Possibly, it was a name invented by the Manichaeans themselves, but only for use in communication with the outside world. Later on, Fortunatus also recognises 'the authority of the Christian faith' (auctoritas fidei christianae) (Augustinus, Contra Fortunatum II, 20; transl. Teske 2006:154), but here again it is within a debate directed at the public which understood itself to be Christian.

Contra Felicem contains, like Contra Fortunatum, summaries of a public debate with Augustine. Unlike the other texts, Felix never uses the noun or adjective 'Manichaean', but he seems to be on the verge of doing so at the end of the first book when he signs in this way: 'Felix the Christian, a worshipper of the law of Manichaeus' (Felix christianus, cultor legis Manichaei', Augustinus, Contra Felicem). Like this signing, many other passages in Felix confirm that 'Christian' and 'Christianity' were his autonyms (e.g. Augustine, Contra Felicem, in Zycha $825: 10 ; 830: 1.4-5 ; 841: 27.28)$.

The Capitula of Faustus of Mileve ${ }^{8}$ are preserved as verbatim excerpts in Augustine's Contra Faustum. The Capitula seem to have been based on a dialogue between Faustus and a real or fictitious Catholic, and in general Faustus only refers to his own group and his opponent's group as 'we' versus 'you'. Only one passage in the long excerpts shows that Faustus could use the adjective 'Manichaean' as a positive autonym: in Book 18, 3 where he speaks about 'Manichaea fides' as the basis for considering Matthew 5:17 a spurious saying of Jesus. The rare use of this autonym in Faustus may mean that he had the same attitude to it as I have suspected in connection with Fortunatus and perhaps also Secundinus: as the designation towards the outside world which is not wrong and which therefore is permitted for use even though it is not the usual self-designation of Faustus and his congregation.

In most passages, Faustus accepts the traditional classification of religious groups from the 2nd century consisting of three 'races'. This classification may already be present in Aristides's Apology, but at least it is found in Tertullian's Ad Nationes (Borleffs I, 8 \& I, 20), where we are informed that the Christians were called 'the third race', 'genus tertium'. Faustus, however, does not use the word 'race' but speaks of three 'religiones' (Contra Faustum 31,2), 'Iudaeos et christianos et gentes' (Contra Faustum 31,2). This implies, however, that Faustus' own group - that is, this 'we' on behalf of whom he is speaking - must be Christians. However, Faustus also repeatedly states this (e.g. Augustinus 1891-1892a, 262:11; 268:17-18; 305:19; 310:14-15; 730:10); especially one should observe how he identifies himself as being of Gentile origin in Book 9,1 but claims that whilst he has become a Christian, others of Gentile origin have become Jews - obviously thinking of the Catholics (Augustinus 1891-1892a, 307:21-24). Corresponding to this, Faustus rejects - with a reference to Adimantus - from the very outset the 'semi-Christians' whom he puts on a par with Judaism (Contra Faustum I.2).

In fact, Faustus frequently uses the Gentile origin of Christians to stress the irrelevance of the Old Testament 8.The English translation used is in Teske (2007). 
(cf. Contra Faustum 13, 1 full of evidence of the word 'Christian' as a Manichaean autonym), but this is mere rhetoric, since he also stresses (e.g. in Contra Faustum 15,1) that in the same way the Jews should leave the Old Testament and its God behind them. Faustus's really important argument consists in the opposition to old and new, Judaism and Christianity: Catholics 'turn the Christian faith into a centaur, neither a complete horse nor a complete man' (christianam denique fidem Hippocentaurum facite, nec equum perfectum nec hominem) (15, 1 transl. Teske 2007:183).

Due to his basic missionary goal, Faustus of course tries to show the common ground between himself and the Catholics - that they do not follow the Jewish law either. So Faustus claims to represent the true version of his opponents' tradition; even though he reserves true Christianity for himself; the Christian tradition of his opponents is also important in order to convince them that they should join him. Faustus seems sometimes to think of Christianity as a great movement with many schools, for instance when he writes that there exist 'christianarum haeresium', including 'catholici' (Augustinus, Contra Faustum 16,7). Faustus also knows about Jewish Christians, as is evident by his mention of the Nazareans or Symmachians, whom he does not seem to consider Christians but whose position he still thinks is more consistent than the Catholic one since acceptance of the Old Testament must also imply observance of its laws (Contra Faustum 19,4). Unlike Secundinus, Faustus never reckons with any positive contents in the word 'Catholic': it is simply the right designation for his opponents (cf. Contra Faustum 23,2, or 'conventu catholico' in 30,3). Amongst the Catholics, however, he refers to the ascetics as 'christianioribus' (Contra Faustum 30,3).

Thus it seems that this line of reasoning must mean either that Catholics are Jews or that they are defective Christians. In an interesting section, however, a different approach is taken by Faustus in that he uses a special distinction between the concepts 'schisma' and 'secta'. Faustus defines the two concepts in this way:

unless I am mistaken, a schism is a group that holds the same opinions and worships with the same ritual as others but wants only a division of the congregation. But a sect is a group that holds opinions far different from others and has established for itself a worship of the deity with a far different ritual. (schisma, nisi fallor, est eadem opinantem atque eodem ritu colentem quo ceteri solo congregationis delectari discidio; secta uero est longe alia opinantem quam ceteri, alio etiam sibi ac longe dissimili ritu diuinitatis instituisse culturam.). (Contra Faustum 20.3; transl. Teske 2007:262)

The setting for this approach is a Catholic accusation against 'us', as Faustus says, for being Gentiles or a schism from the Gentiles because of 'our' worship of the sun (Contra Faustum 20,1). Instead Faustus wants to show that 'we' constitute a 'secta', a community whose opinion and worship is completely different from the opinion and worship of the pagans:

The pagans teach that good and evil, the dark and the bright, the perpetual and the perishable, the changeable and the stable, the bodily and the divine have one principle. I myself hold views quite contrary to these. For I hold that God is the principle of all good things, but that Hyle is the principle of their contraries. For our theologian calls by that name the principle and nature of the evil. (pagani bona et mala, taetra et splendida, perpetua et caduca, mutabilia et certa, corporalia et diuina unum habere principium dogmatizant. his ego ualde contraria sentio, qui bonis omnibus principium fateor deum, contrariis uero hylen; sic enim mali principium ac naturam theologus noster appellat). (Contra Faustum 20.3; transl. Teske 2007:263) ${ }^{9}$

Faustus continues by demonstrating that in accordance with this, the worshipping of the pagans is material, with altars, shrines, images, sacrifices, and incense, whilst 'our' worshipping is spiritual: the altar and the image are in the mind of man, and the prayers are the true sacrifices (Contra Faustum 20.3).

It may seem curious that Faustus does not consider the Gentiles or pagans - he makes use of both words - to be polytheists, but he probably thought of the paganism of Late Antiquity with its stamp of neo-Platonism that attempted to understand the world as a unity originating from one divine principle.

Having established that ' $w \mathrm{e}^{\text {' }}$ and the Gentiles constitute two different 'sects', that is, communities with a completely different doctrine and worship, Faustus tries to demonstrate that the doctrine and worship of the Jews and Catholics are not very different from those of the pagans, which means that the Jews and Catholics are merely two 'schisms' from the pagans. Jews and Catholics alike claim, according to Faustus, that God is the cause of everything; thus their doctrine is basically the same as the doctrine of the pagans. The worship of God amongst the Jews was - with its temple and sacrifices - like the pagan cult. The worship of the Catholics is merely a modification of the pagan cult - Faustus thinks inter alia that the Christian martyr cult had similarities to paganism (Augustinus 1891-1892a, 537:27-29; 538:2-16). Faustus' conclusion is therefore that there is no communal spirit between 'you' and 'us':

It is not true, however, even if you call me a schism of you, though I reverence and worship Christ. For I worship him with another ritual and another faith than you do. (Sed nec uestrum quidem schisma si me dixeris, uerum est, quamuis Christum uenerer et colam, quia alio eum ritu colo et alia fide quam uos.) (Contra Faustum 20.4; transl. Teske 2007:263)

Thus the only real difference between Gentiles, Jews and Catholics is that the two last-mentioned groups have chosen to keep their gatherings separate. Jews and Catholics are two schisms from the pagans (in Augustinus 1891-1892a, 538:16-19). This means that it is only the doctrine and worship of Faustus and his co-religionists which differs from the pagans, and the final conclusion is therefore: 'But if you are looking for sects, there will be no more than two, that is, that of the gentiles and that of us.' (porro autem sectas si quaeras, non plus erunt quam duae, id est gentium et nostra.) (Contra Faustum 20.4; transl. Teske 2007:264).

9.'Hyle' is the Greek word for 'matter'; it is probable that Mani - who may be the 'theologus noster' here - really used this Greek word as a loanword in his Syriac 'theologus noster' here - really used this Greek word as a loanword in his Syriac
writings (cf. Schaeder 1927, inter alia referring both to Faustus and Ephrem the writings (cf. Schaeder 1927,
Syrian's refutations of Mani). 
So in the end, Faustus nevertheless rejects the idea of three races or religions in favour of a distinction between just two 'sects'. Such a distinction, however, may also be more fitting for a dualistic theologian. However, whether the Catholics are viewed as a kind of inferior Christians or as Jews or as constituting a 'secta' together with Jews and Gentiles, it is clear in every context that the deepest conviction of Faustus is that he and his co-religionists are the true Christians. Since Faustus addresses non-Manichaeans, it is possible that this self-designation was mainly used in communication with the outside world, but there can be no doubt that Faustus sincerely understood himself and his group as Christians.

This observation raises, however, new problems since the whole argument of Faustus, his consistent reference to 'we' and 'us', must mean that the Manichaeans were a distinct group - Faustus felt that he belonged to this sharply outlined group in which the members felt solidarity with each other and considered themselves to be a unity, and, furthermore, felt a difference between themselves and certain outsiders. If this is true, the Manichaeans to which Faustus belonged must have possessed some autonyms which could mark their difference in relation to the outside world. The word 'Manichaean' could be such a word, but the fact that it is only used once makes it less probable that it was used frequently by the Manichaeans themselves. The word 'Christians', on the other hand, was not helpful as a distinguishing designation in relation to that outside world which also called itself Christian.

The names 'Christian' and 'Manichaean' are not used in the fragments of Mani's own writings preserved in Latin, the Epistula fundamenti or the Thesaurus, which were probably works primarily intended for use within the Manichaean congregations themselves.

\section{The Manichaean Epitaph from Salona in Dalmatia}

Moving away from the Latin-speaking regions, we find that the fragmentary Greek epitaph from Salona in Dalmatia which may be dated to circa 300 is most interesting. The

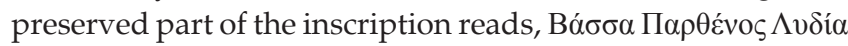

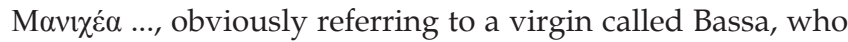
was Manichaean and came from Lydia (Epitaph from Salona 1912:175-177). The epitaph was obviously set up by the Manichaeans themselves, but it may be too bold to conclude that 'Manichaean' was an important autonym in Dalmatia since it was probably the intention that the inscription should also be read by the non-Manichaean neighbours. For this reason the identification of Bassa may have been felt as being necessary.

\section{Manichaean self-designations in texts from Egypt}

The Coptic-Manichaean literary texts that have been found in Medinet Madi and Ismant el-Kharab in Egypt differ not only from the statements made by Secundinus, Felix, Fortunatus and Faustus because of the different cultural and linguistic region but also from these statements because the Coptic texts seem to address themselves to the congregations and not to the non-Manichaean surroundings. Therefore a comparison is difficult. The fact, however, that the word 'Manichaean' is never found in them fits the interpretation that the word is primarily intended for the outside world. Probably the Egyptian Manichaeans would also have recognised the word since there is no polemic against it either. Here it is of interest to mention that the Kellis Agricultural Account Book ${ }^{10}$ mentions

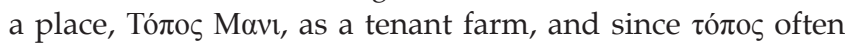
designates a monastery in Byzantine Greek and in Coptic, it has been argued by Roger Bagnall that this could be a reference to the Manichaean monastery mentioned in some private letters from Kellis, even though Mani is otherwise called Manês or Manichaios in Greek texts. ${ }^{11}$ Therefore it seems doubtful that Mani could be a personal name here, and I think it is worth considering whether Mavi could be an abbreviation for $\operatorname{M} \alpha v 1(\chi \alpha i \omega v)$, or ( $\tau \tilde{\omega} v) \operatorname{M\alpha v1}(\chi \alpha i \omega v)$, meaning 'the monastery of the Manichaeans'? This would show that the exonym of the Manichaeans in Kellis was actually 'Manichaeans', also in a commercial context where they themselves must also have had to acknowledge its relevance. However, the fact that there are no other examples of this abbreviation makes it very uncertain.

The clear difference between the Latin-Manichaean texts and the Manichaean texts from Egypt is that no instances of a clear use of the word 'Christian' ( $\chi \rho ı \sigma \tau \iota \alpha v o ́ \varsigma)$ as an autonym have been found in the last-mentioned texts. The word is found once in the form $\chi \rho \eta \sigma \tau \imath \alpha v o ́ s$ in the Manichaean Homilies ${ }^{12}$

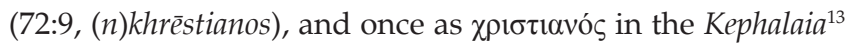
(258:29, nrōme (nkhr)i(s)[tian]os), but in both instances the word occurs in a fragmentary context. ${ }^{14}$ Alexander Böhlig understood the passage in Kephalaia as containing a distinction between 'Christians' and adherents of Mani (Böhlig 1968:204, 262-265). This interpretation is possible, but even if it were true it would seem difficult to generalise on the basis of a single passage. However, it is possible to speculate whether the Kephalaia represent an attempt to dissociate Manichaeism from Christianity - as recently stressed by Iain Gardner (2010). Thus Mani is always called 'the Apostle of Light' in Kephalaia, whilst his own more subordinating self-designation 'Apostle of Jesus Christ' is never found.

Even though the texts never mention the word 'Manichaean' and only rarely the word 'Christian', there are other autonyms: A

10.This is a codex consisting of wooden boards found at Ismant el-Kharab, ancient Kellis, in which the manager of an agricultural estate kept records of produce collected from the tenants and any amounts which they owed. It is edited in Bagnall (1997).

11.Cf. Bagnall (1997:81-82, n. 77) about the meaning of $\tau$ ó $\pi$ os [with references]. Тó $\pi(0 \varsigma)$ Mavt is mentioned twice in the Kellis Agricultural Account Book: 320 and 513. Bagnall (1997:81) writes, 'In the circumstances in which this term occurs, it must be a corporate entity paying rent on leased land'. Later on, the Monk Petros

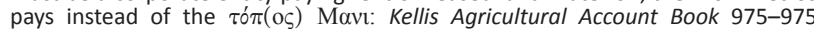

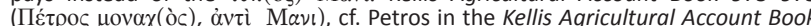
1109, 1433; another monk, Timotheos, is mentioned in the Kellis Agricultural Account Book 1079-1080. Bagnall (1997:83) argues that Mani is eponym of the monastery, and he also writes (1997:84), 'Mani is usually referred to in Greek texts as Manichaios, not as Mani, and some caution may be in order.'

12.Editions: Polotsky (1934); Pedersen (2006).

13.Editions: Schmidt, Polotsky and Böhlig (1940); Böhlig (1966); Funk (1999-2000).

14.The word is not found in the Manichaean Psalm-Book II. 
reference to 'the Elect and the Catechumens' (nsōtp or neklektos mn nkatēkhoumenos e.g. Psalm-Book II, 20:2; 21:22-23; 25:27; $27: 14)$ actually refers to the congregation in its entirety. This is also the case with references to 'the Holy Church' (tekklessia etouabe, e.g. Psalm-Book II, 8:25) and the 'Righteousness' (tdikaiosyne, e.g. Manichaean Homilies 14:9; 15:12-13.). Often autonyms are used that are metaphorically derived from the family sphere, such as 'Sons' (nšêre, e.g. Psalm-Book II, 14:9.16; 42:29; 44:10; 58:24) or 'Sons of the Living Race' (nšêre ntreite etanh). This last-mentioned designation was used by Mani in his Epistles and Living Gospel, preserved in Coptic, ${ }^{15}$ and I have probably found its Syriac form as $b^{e} n a y y \bar{a} d^{e}-\check{s} a r b e t \bar{a}$ $\underline{h a y y}{ }^{e} t \bar{a}$ in some fragments in Manichaean script, even though some letters must be restored. ${ }^{16}$

The Manichaean congregations are often clearly delimited from other religious groups which are called ndogma, that is, the Greek loan-word $\delta$ ó $\mu \alpha$ which may also signify a religious system. It is clearly stated that the Jews and the Magians belong to these $\delta$ ó $\gamma \mu \alpha \tau \alpha$ (Psalm-Book II, 15:5-12), whilst there are no explicit polemics against 'the Christians'. Neither do the expressions 'semi-Christians' or 'Catholics' known from Faustus recur; there are only implicit polemics against such Christian groups, for instance in the Psalm-Book, which states about Jesus: 'He was not born in a womb corrupted' (Psalm-Book II, 52:23-24, cf. also 120:25-26; 121:27-32; 122:19$25 ; 175: 16)$.

Many passages in the Coptic-Manichaean texts demonstrate the centrality for the faith of both Jesus and Mani, and they reckon with their close relationship. This is especially true in the Manichaean Psalm-Book, which also describes the Church as both the Church of Jesus Christ (e.g. II, 56:24; 59:18; 134:1920) and the Church of Manichaios (e.g. II, 8:25; 21:7). This perspective seems more blurred in the Kephalaia, and in spite of the fact that the Psalm-Book and the Kephalaia were found together at Medinet Madi and therefore were probably read and used by the same persons, it seems probable that they have their origin within different groups of Manichaeans.

\section{Conclusion}

Consequently, it seems probable that the Egyptian Manichaeans only seldom used the name and adjective 'Manichaean' - just like their Latin co-religionists. However, unlike them we have no evidence for any use of the name 'Christian' as an autonym. Fluctuating autonyms seem to have been sufficient for internal purposes in Egyptian Manichaeism. The absence of polemics against Christians, however, allows for the possibility that Christians were one of these fluctuating appellations, even though the evidence has not yet been found.

There seems to be common ground between Faustus and the Coptic-Manichaean Psalm-Book as regards the centrality of

15.Cf. the Mani-epistle preserved in P. Kell. Copt. 82:7 (Gardner 2007:68) and the quotation from the First discourse of Mani's Living Gospel (Synaxeis Codex) in Gardner (2007:83)

16.That is, in some fragments (P. 22364) in the papyrus collection in Berlin; cf. the forthcoming edition of them by Nils Arne Pedersen and John Møller Larsen in the Series Syriaca of the Corpus fontium manichaeorum (Brepols).
Jesus. Even though there are many reminiscences of this in the Kephalaia, Jesus does not stand out as markedly central in comparison to many other mythological figures. Since Kephalaia is probably translated from a Syriac original whilst it is not necessary to assume that the Psalm-Book in its entirety had a Syriac original, it would be natural to assume that the original Manichaeism had a less Jesus-centred outlook. In its movement towards the West, however, it became more and more Christianised. This interpretation seems, however, to be in conflict with the impression of a Manichaeism centred around Jesus which we get from the Mani-epistles in Coptic translation from Kellis, which have recently been edited by Iain Gardner and Wolf-Peter Funk (in Gardner 2007:11-93). So maybe the Kephalaia represent a secondary development which, however, was also translated into Western languages like Coptic because of continued personal connections between Manichaean groups in the East and West. If this is the case it is possible that the stronger Christian outlook of Faustus and the Manichaean Psalm-Book are in line with the intentions of Mani. This interpretation also allows for the possibility that Mani called his movement 'the Christians', even if this has only been one of several autonyms used by him. If this was the case, he probably didn't use the Syriac term $k^{e} r \bar{s} \underline{s} \underline{t} y \bar{a} n \bar{e}$ but rather $m^{m} \check{s} \bar{i} \underline{h} \bar{a} y \bar{e}$, corresponding to his self-

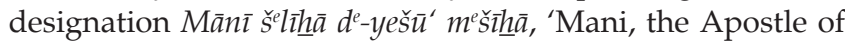
Jesus the Messiah', the Syriac form of which we know from a rock crystal seal which is in the Bibliothèque Nationale in Paris (Menasce \& Guillou 1946).

Unfortunately, evidence is lacking. But a passage which may be read in line with this has sometimes been quoted by Iain Gardner from a yet unpublished Mani-epistle from Medinet Madi, The 7th Ktesiphon Letter. In Gardner's quotation it reads like this: '... on account of our good saviour, our god Christ Jesus, the one in whose name I have chosen you' (Gardner 2007:91 the unpublished Medinet Madi codex Berlin P. 15998).

\section{Acknowledgements Competing interests}

The author declares that he has no financial or personal relationship(s) which may have inappropriately influenced him in writing this article.

\section{References}

Aristides, 2003, 'Apology', in B. Pouderon \& M-J. Pierre (eds.), Aristide, Apologie Introduction, textes critiques, traductions et commentaire par B. Pouderon, M-J. Pierre avec la collaboration de B. Outtier, M. Guiorgadzé, Cerf, Paris. (Sources Chrétiennes, 470).

Augustinus, 1891-1892a, 'Contra Faustum', in J. Zycha (ed.), Sancti Aureli Augustini: De utilitate credendi, De duabus animabus, Contra Fortunatum, Contra Adimantum, Contra Epistulam Fundamenti, Contra Faustum, De natura boni, Epistula Secundini, Contra Secundinum, accedunt Evodii De fide contra Manichaeos, et Commonitorium Augustini quod fertur praefatione utriusque partis praemissa, pp. 79-112, F. Tempsky, Vienna. (Corpus Scriptorum Ecclesiasticorum Latinorum, 25).

Augustinus, 1891-1892b, 'Contra Felicem', in J. Zycha (ed.), Sancti Aureli Augustini: De utilitate credendi, De duabus animabus, Contra Fortunatum, Contra Adimantum, Contra Epistulam Fundamenti, Contra Faustum, De natura boni, Epistula Secundini, Contra Secundinum, accedunt Evodii De fide contra Manichaeos, et Commonitorium Augustini quod fertur praefatione utriusque partis praemissa, pp. 799-852, F. Tempsky, Vienna. (Corpus Scriptorum Ecclesiasticorum Latinorum, 25).

Augustinus, 1891-1892c, 'Contra Fortunatum', in J. Zycha (ed.), Sancti Aureli Augustini: De utilitate credendi, De duabus animabus, Contra Fortunatum, Contra Adimantum, Contra Epistulam Fundamenti, Contra Faustum, De natura boni, Epistula Secundini, Contra Secundinum, accedunt Evodii De fide contra Manichaeos, et Commonitorium Augustini quod fertur praefatione utriusque partis praemissa, pp. 79-112, F. Tempsky, Vienna. (Corpus Scriptorum Ecclesiasticorum Latinorum, 25). 
Augustinus, 1979, 'De haeresibus', in R.V. Plaetse \& C. Beukers (eds.), Sancti Aurelii Augustini: De haeresibus ad Quodvultdeum liber unus. Cura et studio R. Vander Plaetse et C. Beukers. Corpus Christianorum, Series Latina, Aurelii Augustini: opera, pars XIII,2. Sancti Aurelii Augustini: De fide rerum invisibilium, Enchiridion ad Laurentivm, Se fide et spe et caritate De catechizandis rudibus, Sermo ad ad Laurentivm de fide et spe et caritate, De catechizandis rudibus, Sermo ad
catechumenos de symbolo, Sermo de disciplina christiana, Sermo de utilitate catechumenos de symbolo, Sermo de disciplina christiana, Sermo de utilitate ieiunii, Sermo de
Turnhout, Brepols.

Bagnall, R.S., 1997, The Kellis Agricultural Account Book (P. Kell. IV Gr. 96), Oxbow Books, Oxford. (Dakhleh Oasis Project Monograph, 7).

Bickerman, E., 1986, 'The Name of Christians', in E. Bickerman (ed.), Studies in Jewish and Christian history, vol. 3, pp. 139-151, E.J. Brill, Leiden.

Böhlig, A., 1968, Mysterion und Wahrheit. Gesammelte Beiträge zur spätantiken Religionsgeschichte, E.J. Brill, Leiden. (Arbeiten zur Geschichte des späteren Religionsgeschichte, E.J. Brill, Leiden.
Judentums und des Urchristentums, 6).

Gardner, I. (ed.), 2007, Kellis Literary Texts 2, with contributions by M. Choat, M. Franzmann, W.-P. Funk \& K.A. Worp, Oxbow Books, Oxford. (Dakhleh Oasis Project Monograph, 15)

Gardner, I., 2010, 'Towards an understanding of Mani's religious development and the archaeology of Manichaean identity,' in C.M. Cusack \& C. Hartney (eds.), Religion and Retributive Logic: Essays in honour of professor Garry W. Trompf, pp. 147and Retributive Logic: Essays in honour of professor Garry W. Trompf, pp.
158, Brill, Leiden. http://dx.doi.org/10.1163/ej.9789004178809.iv-375.62

Gardner, I. \& Lieu, S.N.C., 2004, Manichaean texts from the Roman Empire, Cambridge University Press, Cambridge. http://dx.doi.org/10.1017/СBO9780511616891

Justin Martyr, 1914, 'Dialogue with Trypho', in E.J. Goodspeed (ed.), Die ältesten Apologeten. Texte mit kurzen Einleitungen, n.p., Vandenhoeck \& Ruprecht, Göttingen. PMid:17821332

Kellis Agricultural Account Book, 1997, in R.S. Bagnall (ed.), The Kellis Agricultura Account Book (P. Kell. IV Gr. 96), Oxbow Books, Oxford. (Dakhleh Oasis Project Monograph, 7).

Kephalaia, 1940, in C. Schmidt, H.J. Polotsky \& A. Böhlig, A. (eds.), Kephalaia, Band I, 1. Hälfte, Manichäische Handschriften der Staatlichen Museen Berlin, W. Kohlhammer, Stuttgart.

Kephalaia, 1966, in A. Böhlig (ed.), Kephalaia, Band I, 2. Hälfte, Manichäische Handschriften der Staatlichen Museen Berlin, W. Kohlhammer, Stuttgart.

Kephalaia, 1999-2000, in W-P. Funk, Kephalaia I, 2, (2 Bände), Manichäische Handschriften der Staatlichen Museen Berlin, W. Kohlhammer, Stuttgart.

Lim, R., 2008, 'The Nomen Manichaeorum and its uses in late antiquity', in E. Iricinsch \& H.M. Zellentin (eds.), Heresy and identity in late antiquity, pp. 143-167, Moh Siebeck, Tübingen. (Texts and Studies in Ancient Judaism, 119).

Manichaean Homilies, 1934, in H.J. Polotsky (ed.), Manichäische Homilien, Manichäische Handschriften der Sammlung A. Chester Beatty, I. W. Kohlhammer, Stuttgart.

Manichaean Homilies, 2006, in N.A. Pedersen (ed.), Manichaean Homilies: with a number of hitherto unpublished fragments, Corpus fontium Manichaeorum Brepols, Turnhout. (Series Coptica, 2).

Mark the Deacon, 1930, 'Life of Porphyry of Gaza', in H. Grégoire \& M-A. Kugener (eds.), Vie de Porphyre, évêque de Gaza. Texte établi, traduit et commenté, Collection Byzantine, publ. sous le patronage de I'Association Guillaume Budé, Société Les Belles-Lettres, Paris.

Markschies, C., 2007, Kaiserzeitliche christliche Theologie und ihre Institutionen. Prolegomena zu einer Geschichte der antiken christlichen Theologie, Moh Siebeck, Tübingen. PMid:17674055
Pliny the Younger, 1972, 'Letter 10:96-97', in W. Heinemann (ed.), Letters and Panegyricus II, Harvard University Press, Cambridge, Mass. (Loeb Classical Library, 59).

Psalm Book II, 1938, in C.R.C. Allberry, A Manichaean Psalm-Book, Part II, Manichaean manuscripts in the Chester Beatty Library, II, W. Kohlhammer, Stuttgart.

Schaeder, H.H., 1927, Urform und Fortbildungen des manichäischen Systems, Vorträge 1924-1925, B.G. Teubner, Leipzig. (Sonderdruck aus Vorträgen der Bibliothek Warburg, 4).

Secundinus, 1891-1892, 'Epistulae', in J. Zycha (ed.), Sancti Aureli Augustini: De utilitate credendi, De duabus animabus, Contra Fortunatum, Contra Adimantum, Contra Epistulam Fundamenti, Contra Faustum, De natura boni, Epistula Secundini, Contra Secundinum, accedunt Evodii De fide contra Manichaeos, et Commonitorium Augustini quod fertur praefatione utriusque partis praemissa Corpus Scriptorum Ecclesiasticorum Latinorum 25 (Sect. VI Pars 1-2), F. Tempsky, Vienna.

Tertullian, 1929, 'Ad Nationes', in J.W.P. Borleffs (ed.), Quinti Septimi Florentis Tertulliani Ad nationes libri duo, n.p., Brill, Leiden.

Teske, R.J., 1995, The works of Saint Augustine: A translation for the $21^{\text {st }}$ century; I/18: Arianism and other heresies: Heresies - Memorandum to Augustine - To Orosius in refutation of the Priscillianists and Origenists - Arian sermon - Answer to an Arian Sermon - Debate with Maximinus - Answer to Maximinus - Answer to an enemy of the Law and the Prophets, Introduction, translation and notes Roland J. Teske. S.J. series editor John E. Rotelle, New City Press, New York.

Teske, R.J., 2006, The works of Saint Augustine: A translation for the $21^{\text {st }}$ century, vol. 1/19, The Manichean debate: The Catholic way of life and the Manichean way of life - The two souls - A debate with Fortunatus, a Manichean - Answer to Adimantus, a disciple of Mani - Answer to the letter of Mani known as the Foundation -Answer to Felix, a Manichean - The nature of the good - Answer to Secundinus, a Manichean, Introduction and notes by Roland Teske, S.J. series editor Boniface Ramsey, New City Press, New York.

Teske, R.J., 2007, The works of Saint Augustine: A translation for the 21st century, 1/20, Answer to Faustus, a Manichean, Introduction, translation and notes by Roland Teske. S.J. series editor Boniface Ramsey, New City Press, New York.

Van Oort, J., 2001, 'Secundini Manichaei Epistula: Roman Manichaean "biblical" argument in the age of Augustine', in J. van Oort, O. Wermelinger \& G. Wurst (eds.), Augustine and Manichaeism in the Latin West: Proceedings of the Fribourg Utrecht Symposium of the International Association of Manichaean Studies (IAMS), pp. 161-173, Brill, Leiden. (Nag Hammadi and Manichaean Studies, 49).

\section{Texts indicated with inventory numbers:}

P. 22364, forthcoming, in Pedersen, N.A. and Larsen, J.M. (eds.), Syriac Texts in Manichaan Script (provisional title), Corpus Fontium Manichaeorum, Series Syriaca 1, Brepols, Turnhout.

P. Kell. Copt. 82, 2007, in I. Gardner (ed.), Kellis Literary Texts 2: Edited by I. Gardner, with contributions by M. Choat, M. Franzmann, W-P. Funk and K.A. Worp, Oxbow Books, Oxford. (Dakhleh Oasis Project Monograph, 15).

\section{Inscriptions:}

Epitaph from Salona, 1912, in M-A. Kugener \& F. Cumont (eds.), Recherches sur le manichéisme, II Extrait de la CXXIII' Homélie de Sévère d'Antioche, III L'inscription de Salone, pp. 175-177, Lamertin, Brussels.

Marcionite inscription, No. 2558, 1968, in W.H. Waddington, Inscriptions grecques et latines de la Syrie recueillies et expliquées, L’Erma di Bretschneider, Paris 1870, Reprint.

Rock crystal seal in the Bibliothèque Nationale, 1946, in P. de Menasce \& A. Guillou, 'Un cachet manichéen de la Bibliothèque Nationale', pp. 81-84, (Revue de I'histoire des religions 131). 